\title{
Seroprevalence and risk factors of herpes simplex virus type- 2 infection among pregnant women in Northeast India
}

Dipankar Biswas ${ }^{1}$, Biswajyoti Borkakoty ${ }^{1}$, Jagadish Mahanta ${ }^{1 *}$, Kamini Walia $^{2}$, Lahari Saikia ${ }^{3}$, Brogen S Akoijam$^{4}$, Lobsang Jampa ${ }^{5}$, Alia Kharkongar ${ }^{6}$ and Eric Zomawia ${ }^{7}$

\begin{abstract}
Background: Herpes simplex virus type-2 (HSV-2) is one of the most common sexually transmitted infections that facilitate human immunodeficiency virus (HIV) acquisition by over two fold or more. The development of HSV-2 control methods as a measure to control HIV epidemic in high HSV-2/HIV areas has become a priority. Two out of the six high HIV prevalent states of India are located in the Northeastern region of India. Due to lack of documented HSV-2 studies from this part of the country; there was a need for estimating the seroprevalence and risk factors of HSV-2 infection in this defined population.
\end{abstract}

Methods: Pregnant women $(n=1640)$ aged18 years and above attending antenatal clinics of tertiary referral hospitals in five Northeastern states of India were screened for type specific HSV-2 IgG antibodies. Blood samples were collected from all the participants after conducting interviews. Univariate and multivariate analyses were performed to identify the risk factors associated with HSV-2 seropositivity.

Results: Overall seroprevalence of HSV-2 infection was 8.7\% (142/1640; 95\% Cl 7.3-10.0) with a highest prevalence of 15.0\% (46/307; 95\% Cl 11.0-19.0) in the state of Arunachal Pradesh. Higher seroprevalence was observed with increasing age (Adj. Odds Ratio [AOR] 1.9 for $22-25$ years old, AOR 2.29 for $>29$ years old). The risk factors associated with HSV-2 seropositives were multiple sex partners (AOR 2.5, $p=0.04$ ), condom nonuser's (AOR 4.7, $p<0.001$ ), early coitarchal age (age of first intercourse) 'less than 18 years' (AOR 9.6, $p=0.04$ ), middle income group (AOR 2.1, $p=0.001$ ) compared to low income group and low level of education (AOR 3.7, $p=0.02$ ) compared to higher education. HSV-2 seropositivity was higher among Christians (12.6\%) compared to Muslims (3.8\%). The most frequent clinical symptoms among HSV-2 seropositives were excess vaginal discharge in last one year $(53.5 \%, 76 / 142)$ and pelvic pain $(26.1 \%, 37 / 142)$. While among subjects with genital ulcers, HSV-2 seroprevalence was $36.8 \%(7 / 19)$.

Conclusions: Overall seroprevalence of HSV-2 infection among pregnant women of Northeast India is relatively low. The generation of awareness among high risk groups may have played key role to limit the infection. The role of vaccination against HSV-2 in near future and elimination of HSV-2 viral shedding along with genital tract inflammation in high HIV/HSV-2 areas may be an option for initiating successful intervention strategies to reduce the transmission and acquisition of HIV infection in Northeast India.

\footnotetext{
* Correspondence: jmahanta@gmail.com

${ }^{1}$ Regional Medical Research Centre, North East Region (Indian Council of

Medical Research), Post Box-105, Dibrugarh-786001, Assam, India

Full list of author information is available at the end of the article
} 


\section{Background}

Herpes Simplex Virus Type-2 (HSV-2) infections is almost always sexually transmitted and is the common cause of genital ulcer disease (GUD) worldwide [1,2]. It is also a good marker of sexual behavior in the population $[1,2]$. Seroprevalence studies show wide variations in infection rates by geographic location. Highest prevalence of HSV-2 has been found in some parts of Africa, America and the lowest in Asia [3]. Globally about 535.5 million were infected with HSV-2 with an overall prevalence of $16.2 \%$ in 2003 [4]. The HSV-2 prevalence in South-Asia in 2003 was estimated to be $29.4 \%$ and $33.2 \%$ among males and females in the age group of 15-49 years respectively [4]. Recent study from India shows HSV-2 prevalence among general population to be around 10\% [5]. HSV-2 is gaining special attention as a significant risk factor for acquisition of human immunodeficiency virus type-1 (HIV-1). HSV-2 infection is also present in 30 to $70 \%$ of those in Europe and 50 to $90 \%$ of those in Africa among patients with HIV infection [6]. HSV-2 increases the risk of HIV-1 transmission by more than two fold and HIV transmission on a per-sexual act basis by up to fivefold and may account for $40-60 \%$ of new HIV infections in high HSV-2 prevalent populations [7-14]. It is assumed that infection with HSV2 disrupts the genital mucosa and provides a portal of entry for HIV, leading to increased susceptibility of HIV in HIV-negative persons. Also, HSV-2 is thought to enhance HIV acquisition due to dense inflammatory infiltrates of CD4/CD8/dendritic cells in the genital tract associated with HSV-2 shedding [15]. Moreover, in HIV-positive persons, infection with HSV-2 accelerates replication and genital shedding of the virus, thus such individuals are more likely to transmit HIV $[16,17]$. Increasing evidence of HSV-2 facilitating HIV acquisition and transmission makes the development of HSV control methods a priority $[1,6]$. Also, other meta-analysis data from general population among women showed that in prevalent HSV-2 infection, HIV acquisition increased by over a three-fold [18]. A study by Nagot et al. highlights the association of HSV-2 with significantly higher viral load of HIV-1 in plasma and in genital secretions in women with sexually acquired HIV-1 [17]. This finding has direct clinical implications, suggesting that elimination of HSV-2 viral shedding and genital tract inflammation can reduce the transmission and acquisition of HIV infection.

The role of HSV-2 as a biological cofactor in HIV acquisition and transmission, which may have contributed substantially to HIV infections particularly by facilitating HIV spread among the low-risk population with stable longterm sexual partnerships [19]. A study conducted in four cities of Africa indicated that in the two West African cities with lower HSV-2 prevalence, HIV remained concentrated in higher risk groups. However, in the cities with high HSV-2 prevalence, HIV transmission was observed in a large fraction of the population [20]. These results suggest that HSV-2 may be the trigger for the explosive expansion of HIV and were also corroborated by the epidemiological synergy study of HIV and HSV-2 [19]. The increasing evidence that HSV-2 facilitates HIV acquisition and transmission and the synergistic effect of HSV-2 on HIV, makes the development of HSV-2 control methods a priority.

In Northeast India, the epidemic of HIV-1 is driven mainly by the IDU population in the State of Manipur, Mizoram and Nagaland. The state of Manipur has the highest HIV prevalence in the country (1.67\% in 2006) [21]. In a recent study from this Institute, the HIV-1 prevalence was found to vary between $23 \%$-32\% among the IDUs of Manipur [22]. Female sex workers (FSWs) are common in scattered locations in few northeast states of India. One recent study from this Institute has found HIV-1 prevalence of $13.6 \%$ in FSWs of Nagaland, a state in northeast India (unpublished data of the authors). The population of Northeast India is heterogeneous and there is a huge socio-cultural difference among the states. HIV preventive measures have been the cornerstone in the efforts to halt the epidemic amongst IDUs and FSWs of Northeast India. Over the years, HIV has made in-roads into the general population of the Northeastern states. The average HIV prevalence among women attending antenatal clinics in India is $0.48 \%$. The HIV prevalence in the antenatal clinic attendees in the Northeastern state of Manipur was $1.25 \%$ and in Mizoram was $1.0 \%$ in 2006, which was among the highest in the country in this group of population [21].

Considering the above facts, this study was conducted to assess the seroprevalence of HSV-2 and its risk factors among pregnant women (antenatal clinic attendees) in five North-eastern states of India (viz. Assam, Arunachal Pradesh, Manipur, Meghalaya, and Mizoram). Since, more than $75 \%$ of primary genital herpes virus infections are asymptomatic [23], the seroepidemiological studies are critical in understanding the pattern and distribution of infection within the population to understand the HSV-2 related HIV transmission dynamic in the different communities of Northeast India.

\section{Methods}

\section{Study area and Population}

This is a cross-sectional study which was conducted in five, out of eight Northeastern states of India to understand the epidemiology and role of risk factors associated with HSV-2 seroprevalence with an aim focused towards prevention. A total of 1640 pregnant woman attending antenatal clinics (ANCs) in five tertiary referral hospitals representing the general population of each of the five Northeastern states i.e., Arunachal Pradesh, Assam, Manipur, Meghalaya, and Mizoram were enrolled in the 
study between April 2007 and March 2009. The present study was approved by institutional human ethical committee of the Regional Medical Research Centre. Trained field investigators had enrolled pregnant women aged 18 years and above who had consented for the study. Pregnant women in labor or under serious medical conditions were excluded from the study.

\section{Data collection}

A predesigned and pretested structured questionnaire having information on socio-demographic variables such as age, religion, education, occupation, type of family, geographic location, annual income, gestational weeks, and risk factors that may be associated with sexually transmitted diseases like number of sex partners in previous one year, use of condom, alcohol consumption, coitarchal age, commercial sex worker, and type of sex partner were recorded. The clinical history, signs \& symptoms associated with genito-pelvic infections, including previous history of genital ulcer, pelvic pain, and excessive vaginal discharge, pain during sexual intercourse, genital warts, and swelling in the groin were also recorded. The participants were interviewed confidentially and examined by qualified gynaecologists.

\section{Specimen collection and laboratory test}

Specimen of $5 \mathrm{ml}$ venous blood were collected from all the enrolled subjects in K3 EDTA tubes and immediately kept at $+4^{\circ} \mathrm{C}$. Plasma samples were separated on the same day and stored at $-20^{\circ} \mathrm{C}$ freezer in aliquots until analyzed. Plasma samples were subjected for HSV-2 IgG detection using type specific HSV-2 glycoprotein (gpG2) IgG EIA kit (HerpeSelect 2 ELISA IgG, Focus Diagnostics, USA) as per manufacture's manual. The cut-off value used to determine a positive test on this kit was > 1.10. Index value between 1.1 and 0.9 were considered equivocal and index values below 0.9 were considered negative as per the kit instruction manual. The equivocal samples were re-tested with the same kit. The samples that were found to be equivocal in the repeat test, a second samples were collected from the same subjects after 1-2 months for reconfirmation. All the positive samples and randomly selected $10 \%$ negative samples were retested for confirmation.

\section{Statistical analyses}

Data were entered and analyzed in SPSS version 13.0 statistical software (SPSS, Chicago, USA). The statistical significance of HSV-2 seroprevalence with other associated factors (socio-demographic, risk variables and clinical findings) was obtained using univariate analysis. The multivariate analysis was performed by binary logistic regression using Wald Backward elimination method with probability for stepwise entry at $p=0.05$ and removal at $p=0.1$, to find the association between categorical variables with HSV-2 seroprevalence. Odds ratios (OR) were calculated using Binary logistic regression analysis where first category (having lowest seroprevalence) was used as a reference in each group. OR and their 95\% confidence intervals (95\% CI) were documented to indicate magnitude and direction of associations. The variables showing significant interactions were analyzed separately. The level of statistical significance was set at $p \leq 0.05$.

\section{Results}

A total of 1640 pregnant women from five Northeastern states of India were studied. The median age of the study subjects was 25 years $(\mathrm{SD} \pm 4.7)$ and ranged from 18 to 46 years. The literacy rate of the enrolled subjects was $84.5 \%(n=1386)$, among which $49.3 \%(n=809)$ were educated up to primary level. Majority of the subjects were housewife $79.9 \%(n=1310)$, lived in nuclear family $57.9 \%(n=950)$, and were from low income group $71.8 \%(n=1177)$. Within the enrolled subjects, $67.0 \%(n=1099)$ were in $3^{\text {rd }}$ trimester of pregnancy and $43.2 \%(n=708)$ were primi-gravida with a median of two gravida $(2 \pm 1.8)$.

State-wise, socio-demographic variables of the study subjects are listed in Table 1. The demographic composition in the present study reveals that Christians accounted for the major chunk of subjects in the state of Mizoram (96.1\%), Meghalaya (70.0\%) followed by Arunachal Pradesh (35.2\%), whereas Hindus followed by Muslims were found to be the major religion of the study cohort in Assam (90.3\% and 8.7\%) and Manipur (86.1\% and $13.9 \%$ ) respectively. Also, it was observed that $84.9 \%$ of the enrolled Muslim subjects were from low income group compared to $49.4 \%$ and $39.5 \%$ in Hindus and Christians respectively. Overall 11.7\% (192/1640) enrolled subjects were migrants with highest number in Arunachal Pradesh (19.9\%) followed by Meghalaya (19.5\%) and Mizoram (10.8\%).

\section{Seroprevalence}

The overall HSV-2 seroprevalence was 8.7\% (142/1640; 95\% CI 7.3-10.0) with a highest prevalence of $15.0 \%$ (95\% CI 11.0-19.0) in the state Arunachal Pradesh followed by Mizoram at $13.4 \%$ (95\% CI 9.0-17.8), Meghalaya at $10.5 \%$ (95\% CI 7.5-13.5), Assam at 4.0\% (95\% CI 1.8-6.2) and Manipur at 2.7\% (95\% CI 1.1-4.3). The increasing HSV-2 seroprevalence was observed with the increasing age e.g. 6.5\% seroprevalence in '18-21 years' age group to $9.4 \%$ in '29 years and above' with a significant peak of $10.5 \%$ in '22-25 years' (Table 2). HSV-2 seroprevalence was $17.9 \%$ (approaching significance $p=$ 0.06 ) in 1 st trimester of pregnancy compared to $6.8 \%$ in 2nd and $9.3 \%$ in $3 \mathrm{rd}$ trimester. Though HSV-2 
Table 1 State wise socio-demographic variables of the study subjects, Northeast India $(n=1640)$

\begin{tabular}{|c|c|c|c|c|c|}
\hline Variables (total) & $\begin{array}{c}\text { Manipur } \\
\text { n (\%) }\end{array}$ & $\begin{array}{c}\text { Assam } \\
\mathrm{n}(\%)\end{array}$ & $\begin{array}{l}\text { Meghalaya } \\
\text { n (\%) }\end{array}$ & $\begin{array}{c}\text { Arunachal Pradesh } \\
\text { n (\%) }\end{array}$ & $\begin{array}{c}\text { Mizoram } \\
\mathrm{n}(\%)\end{array}$ \\
\hline Subjects recruited (1640) & 402 & 300 & 400 & 307 & 231 \\
\hline \multicolumn{6}{|l|}{ Age groups } \\
\hline 18 to 21 yrs (355) & $75(18.7)$ & $77(25.7)$ & 145(36.2) & $30(9.8)$ & $28(12.1)$ \\
\hline 22 to 25 yrs (592) & 125(31.1) & 137(45.6) & 113(28.3) & 140(45.6) & 77(33.3) \\
\hline 26 to 29 yrs (385) & 103(25.6) & $63(21.0)$ & $77(19.2)$ & $85(27.7)$ & $57(24.7)$ \\
\hline$>29$ yrs (308) & $99(24.6)$ & $23(7.7)$ & $65(16.3)$ & $52(16.9)$ & $69(29.9)$ \\
\hline \multicolumn{6}{|l|}{ Religion } \\
\hline Hindu (844) & $346(86.1)$ & 271(90.3) & $93(23.2)$ & $125(40.7)$ & $9(3.9)$ \\
\hline Christian (611) & - & $1(0.3)$ & $280(70.0)$ & 108(35.2) & $222(96.1)$ \\
\hline Muslim (106) & $56(13.9)$ & $26(8.7)$ & $7(1.8)$ & $17(5.5)$ & - \\
\hline Others (79) & - & $2(0.7)$ & $20(5.0)$ & $57(18.6)$ & - \\
\hline \multicolumn{6}{|l|}{ Occupation } \\
\hline House wife (1310) & $341(84.8)$ & 293(97.7) & $328(82.0)$ & 168(54.7) & 180(77.9) \\
\hline Regular employee (110) & $7(1.7)$ & $1(0.3)$ & $17(4.2)$ & $79(25.7)$ & $6(2.6)$ \\
\hline Unskilled worker (75) & 39(9.7) & $6(2.0)$ & $50(12.5)$ & $37(12.1)$ & 43(18.6) \\
\hline Business (45) & $15(3.7)$ & - & $5(1.3)$ & $23(7.5)$ & $2(0.9)$ \\
\hline \multicolumn{6}{|l|}{ Education } \\
\hline Primary \& less (1063) & $252(62.7)$ & $231(77.0)$ & $278(69.5)$ & $166(54.1)$ & 136(58.9) \\
\hline Secondary (462) & 105(26.1) & $66(22.0)$ & $101(25.2)$ & 98(31.9) & $92(39.8)$ \\
\hline Graduate \& above (115) & $45(11.2)$ & $3(1.0)$ & $21(5.3)$ & $43(14.0)$ & $3(1.3)$ \\
\hline \multicolumn{6}{|l|}{ Type of family } \\
\hline Nuclear (950) & 232(57.7) & $144(48.0)$ & $238(59.5)$ & $211(68.7)$ & $125(54.1)$ \\
\hline Joint (616) & 169(42.0) & $147(49.0)$ & 156(39.0) & $42(13.7)$ & $102(44.2)$ \\
\hline Single (74) & $1(0.3)$ & $9(3.0)$ & $6(1.5)$ & $54(17.6)$ & $4(1.7)$ \\
\hline \multicolumn{6}{|l|}{ Income group } \\
\hline Low (1177) & 247(61.4) & $262(87.3)$ & $324(81.0)$ & $160(52.1)$ & 184(79.6) \\
\hline Middle \& high (463) & 155(38.6) & $38(12.67)$ & $76(19.0)$ & $147(47.88)$ & $47(20.35)$ \\
\hline Migrant labor (192) & $14(3.5 \%)$ & $14(4.7 \%)$ & $78(19.5)$ & $61(19.9 \%)$ & $25(10.8 \%)$ \\
\hline \multicolumn{6}{|l|}{ Duration of Pregnancy } \\
\hline 1-12 weeks (28) & - & $9(3.0)$ & $19(4.8)$ & - & - \\
\hline 13-28 weeks (513) & 100(24.9) & 205(68.3) & 131(32.7) & $39(12.7)$ & $38(16.5)$ \\
\hline 29-42 weeks (1099) & $302(75.1)$ & $86(28.7)$ & $250(62.5)$ & $268(87.3)$ & 193(83.5) \\
\hline Commercial sex worker (8) & $2(0.5 \%)$ & - & - & $5(1.6 \%)$ & $1(0.4 \%)$ \\
\hline
\end{tabular}

seroprevalence was higher among migrants $(12.0 \%)$ compared to the locals $(8.2 \%)$, it was not significant statistically $(p=0.08)$.

\section{Risk Factors}

The univariate and multivariate analysis of risk factors associated with HSV-2 seroprevalence is presented in Table 2. In univariate analysis, it was found that HSV-2 seroprevalence differs significantly $(p<0.001)$ among the subjects of different religion in North-east India. Subjects from Christian community were at higher risk (AOR 3.5, 95\% CI 1.2-10.1, $p=0.02$ ) of getting infection with reference to Muslims (analyzed separately because of significant interaction with 'state'). On multivariate analysis, it was found that subjects in the state of Arunachal Pradesh has the highest risk of HSV-2 compared to the state of Manipur (AOR 11.5, 95\% CI 5.2-25.5, $p<$ $0.001)$. The risk-factors that had a significant association with HSV-2 were condom never users compared to regular or occasional users (AOR, 4.7, 95\% CI 2.5-8.9, $p<$ 0.001 ); coitarchal age less than 18 years (AOR 9.6, 95\% CI 1.1-81.6, $p=0.04$ ); more than one sex partner (AOR 2.5, 95\% CI 1.1-6.1, $p=0.04)$; middle or high income compared to low income subjects (AOR 2.2, 95\% CI $1.4-3.3, p=0.001$ ); subjects from nuclear family (AOR 1.7, 95\% CI 1.1-2.6, $p=0.02$ ); subjects with low level of education (AOR 3.7, 95\% CI 1.3-10.7, $p=0.02$ ) and subjects having regular earning through a regular job (AOR $3.4,95 \%$ CI $1.3-8.8, p=0.01$ ) [see table 2]. Though HSV-2 seroprevalence was higher amongst alcoholics (12.1\%) compared to non-alcoholics $(7.7 \%)$, it was not significant in multivariate analysis. 
Table 2 Risk factors associated with HSV-2 seroprevalence among pregnant women in Northeast India (n = 1640)

\begin{tabular}{|c|c|c|c|c|c|c|c|}
\hline \multirow[t]{2}{*}{ Characteristics (n) } & \multirow{2}{*}{$\begin{array}{c}\text { HSV-2 Sero } \\
\text { Prevalence } \\
\text { n (\%) }\end{array}$} & \multicolumn{3}{|c|}{ Univariate analysis } & \multicolumn{3}{|c|}{ Multivariate analysis } \\
\hline & & OR & $\begin{array}{l}95 \% \\
\text { C.I. }\end{array}$ & $p$ value & AOR & $\begin{array}{c}95 \% \\
\text { C.I. }\end{array}$ & $p$ value \\
\hline \multicolumn{8}{|l|}{ Age groups } \\
\hline 18 to 21 yrs (355) & $23(6.5)$ & Ref & - & - & Ref & - & - \\
\hline 22 to 25 yrs (592) & $62(10.5)$ & 1.69 & $1.03-2.78$ & 0.04 & 1.90 & $1.09-3.31$ & 0.02 \\
\hline 26 to 29 yrs (385) & $28(7.3)$ & 1.13 & $0.64-2.01$ & 0.67 & 1.52 & $0.81-2.87$ & 0.19 \\
\hline$>29$ yrs (308) & $29(9.4)$ & 1.50 & $0.85-2.65$ & 0.16 & 2.29 & $1.19-4.39$ & 0.01 \\
\hline \multicolumn{8}{|l|}{ States } \\
\hline Manipur (402) & $11(2.7)$ & Ref & - & - & Ref & - & - \\
\hline Assam (300) & $12(4.0)$ & 1.48 & $0.64-3.40$ & 0.36 & 2.30 & $0.96-5.48$ & 0.06 \\
\hline Meghalaya (400) & $42(10.5)$ & 4.17 & $2.11-8.22$ & $<0.001$ & 5.13 & $2.52-10.43$ & $<0.001$ \\
\hline Mizoram (231) & $31(13.4)$ & 5.51 & $2.71-11.2$ & $<0.001$ & 4.51 & $2.15-9.49$ & $<0.001$ \\
\hline Arunachal Pradesh (307) & $46(15.0)$ & 6.27 & $3.19-12.3$ & $<0.001$ & 11.49 & $5.18-25.48$ & $<0.001$ \\
\hline \multicolumn{8}{|l|}{ Occupation } \\
\hline Unskilled worker (75) & $12(6.9)$ & Ref & - & - & Ref & - & - \\
\hline House wife (1310) & $105(8.0)$ & 1.18 & $0.64-2.20$ & 0.59 & 1.55 & $0.80-3.00$ & 0.20 \\
\hline Business (45) & $6(13.3)$ & 2.09 & $0.74-5.92$ & 0.17 & 2.28 & $0.72-7.20$ & 0.16 \\
\hline Regular employee (110) & $19(17.3)$ & 2.84 & $1.32-6.11$ & 0.008 & 3.45 & $1.35-8.81$ & 0.01 \\
\hline \multicolumn{8}{|l|}{ Education } \\
\hline Graduate \& above (115) & $6(5.2)$ & Ref & - & - & Ref & - & - \\
\hline Secondary (462) & $42(9.1)$ & 1.82 & $0.75-4.38$ & 0.18 & 2.57 & $0.92-7.19$ & 0.07 \\
\hline Primary \& less (1063) & $94(8.8)$ & 1.76 & $0.75-4.12$ & 0.19 & 3.73 & $1.29-10.75$ & 0.02 \\
\hline \multicolumn{8}{|l|}{ Type of family } \\
\hline Joint (616) & $35(5.7)$ & Ref & - & - & Ref & - & - \\
\hline Nuclear (990) & 99 (10.4) & 1.93 & $1.30-2.88$ & 0.001 & 1.66 & $1.08-2.57$ & 0.02 \\
\hline Single (74) & $8(10.8)$ & 2.01 & $0.90-4.52$ & 0.090 & 1.72 & $0.64-4.64$ & 0.28 \\
\hline \multicolumn{8}{|l|}{ Income group } \\
\hline Low (1177) & $85(7.2)$ & Ref & - & - & Ref & - & - \\
\hline Middle (463) & $57(12.3)$ & 1.80 & $1.27-2.57$ & 0.001 & 2.15 & $1.39-3.31$ & 0.001 \\
\hline \multicolumn{8}{|l|}{ Coitarchal age } \\
\hline$>30$ yrs (29) & $1(3.4)$ & Ref & - & - & Ref & - & - \\
\hline 18 to 30 yrs (1335) & $91(6.8)$ & 2.05 & $0.28-15.2$ & 0.48 & 2.36 & $0.29-19.40$ & 0.43 \\
\hline$<18$ yrs $(218)$ & $48(22.0)$ & 7.91 & $1.05-59.6$ & 0.045 & 9.59 & $1.13-81.65$ & 0.04 \\
\hline No response (58) & $2(3.4)$ & 1.00 & $0.09-11.5$ & 1.00 & 0.60 & $0.05-7.83$ & 0.70 \\
\hline \multicolumn{8}{|l|}{ Alcohol use } \\
\hline Never user (1267) & $97(7.7)$ & Ref & - & - & Ref & - & - \\
\hline Regular \& occasional users (373) & $45(12.1)$ & 1.66 & $1.14-2.41$ & 0.008 & 1.18 & $0.74-1.86$ & 0.49 \\
\hline \multicolumn{8}{|l|}{ Sex partner } \\
\hline Single (1601) & $134(8.4)$ & Ref & - & - & Ref & - & - \\
\hline More than 1 (39) & $8(20.5)$ & 2.83 & $1.27-6.27$ & 0.01 & 2.50 & $1.02-6.13$ & 0.045 \\
\hline \multicolumn{8}{|l|}{ Condom use } \\
\hline Regular \& occasional users (341) & $18(5.3)$ & Ref & - & - & Ref & - & - \\
\hline Never user (1299) & $124(9.5)$ & 1.9 & $1.14-3.15$ & 0.01 & 4.73 & $2.51-8.91$ & $<0.001$ \\
\hline
\end{tabular}

AOR: Adjusted Odds Ratio; $95 \%$ Cl: $95 \%$ confidence interval; Coitarchal age: age at first intercourse

The most frequent clinical symptoms among HSV-2 seropositives were excess vaginal discharge in last one year $(53.5 \%, 76 / 142)$ and pelvic pain $(26.1 \%, 37 / 142)$. HSV-2 seroprevalence was highest, $36.8 \%$ (7/19; 95\% CI 15.2-58.5) among subjects with genital ulcers. The association of clinical signs \& symptoms with HSV-2 seroprevalence is presented in Table 3. Significantly higher HSV-2 seroprevalence was observed among the subjects with genital ulcer (AOR 4.1, 95\% CI 1.4$12.2, p=0.01$ ), history of pelvic pain (AOR 2.2, 95\% 


\begin{tabular}{|c|c|c|c|c|c|c|c|c|}
\hline \multirow{2}{*}{$\begin{array}{l}\text { Clinical sign } \\
\& \\
\text { symptoms }\end{array}$} & \multirow[t]{2}{*}{ Response/findings (n) } & \multirow{2}{*}{$\begin{array}{c}\text { HSV-2 Sero prevalence } \\
\text { n (\%) }\end{array}$} & \multicolumn{3}{|c|}{ Univariate analysis } & \multicolumn{3}{|c|}{ Multivariate analysis } \\
\hline & & & OR & $95 \% \mathrm{Cl}$ & $\begin{array}{c}P \\
\text { value }\end{array}$ & AOR & $95 \% \mathrm{Cl}$ & $\begin{array}{c}P \\
\text { value }\end{array}$ \\
\hline \multirow[t]{2}{*}{ Cervicitis } & No (1447) & $107(7.4)$ & Ref & - & - & Ref & - & - \\
\hline & Yes (193) & $35(18.1)$ & 2.80 & $1.8-4.2$ & $<0.001$ & 2.14 & $1.36-3.38$ & 0.001 \\
\hline \multirow[t]{2}{*}{ Genital ulcer } & No (1621) & $135(8.3)$ & Ref & - & - & Ref & - & - \\
\hline & Yes (19) & $07(36.8)$ & 6.42 & $2.5-16.6$ & $<0.001$ & 4.11 & $1.38-12.21$ & 0.011 \\
\hline \multirow[t]{2}{*}{ Pelvic pain } & No (1423) & $105(7.4)$ & Ref & - & - & Ref & - & - \\
\hline & Yes (217) & $37(17.1)$ & 2.58 & $1.72-3.87$ & $<0.001$ & 2.20 & $1.40-3.45$ & 0.001 \\
\hline Excess vaginal discharge & $\begin{array}{l}\text { No (1003) } \\
\text { Yes (637) }\end{array}$ & $\begin{array}{l}66(6.6) \\
76(11.9)\end{array}$ & $\begin{array}{l}\text { Ref } \\
1.92\end{array}$ & $\stackrel{-}{1.36-2.72}$ & $<0.001$ & $\begin{array}{l}\text { Ref } \\
1.46\end{array}$ & $\begin{array}{c}- \\
1.00-2.15\end{array}$ & $\begin{array}{c}- \\
0.053\end{array}$ \\
\hline
\end{tabular}

AOR: Adjusted Odds Ratio; 95\% Cl: 95\% confidence interval

CI 1.4-3.5, $p=0.001$ ) and cervicitis (AOR 2.1, 95\% CI $1.4-3.4, p=0.001)$.

\section{Discussion}

The conceptual importance of this study was largely based on the increasing evidence that HSV-2 infection has a synergistic activity on acquiring HIV infection and this has been well documented [6-14,16,17]. Since there were virtually no data on the prevalence of HSV-2 in the community of Northeastern states of India, there was a need to know the prevalence of this infection to plan an intervention strategy especially in the high HIV prevalent states of Northeast India. This sero-epidemiological study was based on detection of HSV-2 IgG antibodies against type specific glycoprotein G2. The HerpeSelect HSV-2 IgG ELISA test (Focus Diagnostics), in an evaluation study demonstrated a sensitivity of $96 \%$ in a group of pregnant women and $95 \%$ in a STD population of men and women. The specificity of Focus HSV-2 ELISA was also high in these groups i.e. $97 \%$ in pregnant women and $96 \%$ in the STD population [24]. The relative specificity of the assay as compared to Western Blot assay (Gold standard) in a low prevalent population was shown to be $98.7 \%$ and relative sensitivity $100 \%$ as per instruction manual of the kit. Though, the kit used in our study has a very high sensitivity and specificity, the false positivity of HSV-2 in low prevalence area cannot be ruled out. We also acknowledge the limitations of statistical test used in this cross-sectional study which may be prone to residual confounding effect in comparison to case control studies.

Our study detected a significant geographical variation of HSV-2 seroprevalence which has also been observed in an earlier study [22]. Community based studies conducted elsewhere in India also reported wide variations in seroprevalence [3,25]. One study from Chennai based on study of around 30 communities, reported a wide variation in prevalence of HSV-2 from 4.1 to $49.1 \%$ with a mean prevalence of $15.3 \%$ [3]. Studies conducted among the high risk groups showed highest seroprevalence $(40 \%$ to $70 \%)$ [12,26-28]. In our study, we expected highest HSV-2 prevalence in the state of Manipur, which has the highest HIV prevalence in India and expected lowest in the state of Arunachal Pradesh which has the lowest HIV prevalence in the country [21]. But to the contrary, we detected the lowest HSV-2 seroprevalence in the state of Manipur (2.7\%) and highest in the state of Arunachal Pradesh (15\%). This may be the result of the widespread public awareness in the state of Manipur in last two decades on practice of safe sex to fight HIV epidemic in that state, whereas such public awareness drive is virtually absent in the state of Arunachal Pradesh.

In comparison to other National and international studies, our finding of $8.7 \%$ HSV-2 seroprevalence was relatively low. A community based study in New Delhi reported $8.6 \%$ seroprevalence among females, which is similar to our findings [25]. Higher seroprevalence were reported from Chennai (15.3\%) in South India [3], central India (12.4\%) [29] and Gujarat (23.3\%) in Western India among women attending gynaecology OPD [30]. Seroprevalence of $7.5 \%$ among pregnant women from Jammu \& Kashmir, North India [31], and 7.0\% among females from Andhra Pradesh, South India was reported in a community based study [32]. The National Health and Nutrition Examination Survey (NHANES) surveillance data from USA found HSV-2 seroprevalence of $20.9 \%$ in US females aged ' 14 to 49 years', with an overall seroprevalence of $16.2 \%$ [33]. The HSV-2 seroprevalence among 15 to 49 years females in South Asian region was reported to be $33.2 \%$, whereas it was $19.4 \%$ globally [4].

In comparison to low income group, we observed significantly higher HSV-2 seroprevalence among middle or high income group. Studies in India and abroad also observed association of socio-economic status (SES) 
with HSV-2 seroprevalence [3,25,34]. This has been observed from both the previously mentioned study from New Delhi [25], and Chennai [3]. In the study from New Delhi, HSV-2 seroprevalence was found to be more common in the urban middle class community with higher average monthly income (12.6\%) as compared to urban slum with lower average monthly income (3.1\%) [25]. While, the study from Chennai reported an independent association of community-level factors like SES with HSV-2 sero-prevalence [3]. In another study from Australia, found that HSV-2 seroprevalence was significantly lower in areas of low SES than in high SES areas among both men and women for all ages [34]. However, some other studies have reported significant association between HSV-2 seropositivity and lower income [35]. Though this paradox would be hard to explain, it may be related to difference in risk behavior among the different income groups. It was seen in our study that majority of Muslim subjects (84.9\%, 90/ 106) were from low income group. It was also observed that Muslim subjects had the lowest HSV-2 seroprevalence (3.8\%) compared to Hindu (5.8\%) and Christians (12.6\%), which may explain this finding in our study.

It is generally being observed that HSV-2 seroprevalence increases with increasing age [25,33,36,37]. In our study we also observed an increase in prevalence with age $(6.5 \%$ to $9.4 \%)$ but with a peak in prevalence $(10.5 \%)$ in the 22-25 years age group. This may reflect a relatively recent introduction of HSV-2 in the community which may have resulted in higher prevalence among sexually active younger subjects rather than the older subjects which didn't had the exposure to the virus when they were sexually active in the past.

The risk factors for HSV-2 are well known and include polygamous relationships/multiple sex partners', unsafe sex, increasing numbers of lifetime partners and association with other STIs or GUD etc $[7,16,35,38]$. The strongest predictor for infection is a person's number of lifetime sex partners [36]. In our study, it was also observed that subjects with multiple sex partners had significantly higher HSV-2 seroprevalence compared to single sex partner. Moreover, it was seen that higher coitarchal age was associated with a lower chance of HSV-2 infection. The association of coitarchal age less than 18 years or early age of first sex with seroprevalence was also observed in other studies [39,40]. In this study, higher seroprevalence was found among Christians versus Muslims. This difference in prevalence with religion (3.8\% in Muslim compared to $12.6 \%$ among Christians), may be due to practice of male circumcision at infancy or early childhood by the spouses of the pregnant women among Muslims. Male circumcision lowers the prevalence of HSV-2 or HPV has been reported in some studies [41]. Subjects from nuclear family, middle income group, low level of education, having regular source of income, had a higher risk of HSV-2 infections. Modifiable risk factors included, low coitarchal age, never or low condom usage, and multiple sex partners, which can be incorporated in awareness programs to lower the transmission of HSV-2 in the community.

Our study found a significantly higher HSV-2 seropositive amongst subjects with sign and symptoms of genito-pelvic infections such as genital ulcer, pelvic pain and cervicitis. In our study it was found that HSV-2 prevalence was higher among subjects with excessive vaginal discharge but was not significant statistically. The subjects with history of genital ulcers had the highest HSV-2 seroprevalence among the study variables. Also, it is known that majority of HSV2 seropositive people shed virus whether or not they are aware of recurrent genital lesions. Genital tract inflammation is evident in "asymptomatic shedders" [42]. Studies conducted in Surat and Delhi also observed higher HSV-2 seroprevalence in subjects with vaginal discharge and lower abdominal or low backache $[30,43]$.

In Northeast India, the impact of HSV-2 infection in driving the HIV-1 epidemics is still not clear. Although HSV-2 vaccines are still in clinical trials, acyclovir when given continuously or episodically can reduce recurrence of ulcers in individuals with HSV-2 infection. Though clinical trials in Africa on use of acyclovir did not reduce the risk of linked transmission of HIV-1 to couples, however it showed a reduction of plasma HIV-1 RNA level as well as $73 \%$ reduction in occurrence of genital ulcers due to HSV-2 [44]. Multiple studies have shown that a persistent increase of $0.5 \log _{10}$ copy per millilitre in the plasma HIV-1 level is associated with a clinically shortened time for progression to AIDS [6]. The demonstration that daily anti-HSV-2 therapy can reduce the viral load by this amount is thus of direct importance for treatment. The study by Nagot et al. underlines the findings of a 1989 study showing that zidovudine plus acyclovir (ACV) was associated with prolonged survival, as compared with zidovudine alone [6]. The data from another controlled trial with HSV-2 suppressive therapy with acyclovir showed no evidence of decreasing the incidence of HIV in Tanzania [45]. This landmark study fails to demonstrate the role of acyclovir in decreasing the transmission of HIV among HSV-2 seropositives. This is in contrary to the fact that acyclovir is activated into a human herpes virus (HHV) DNA polymerase inhibitor exclusively by HHV kinases. It suppresses HIV-1 in HHV coinfected human tissues but not in HHV free tissue or cell cultures [46]. Acyclovir treatment in patients coinfected with HSV/HIV has been observed to alter the disease course and decrease HIV viral load which attributed to indirect effects of HSV suppression on HIV replication [47]. Also, if we 
accept the fact that HSV-2 increases the risk of HIV acquisition by 2-3 folds, than suppression of HSV-2 by ACV which results in decrease genial ulceration and inflammation would be expected to influence HIV acquisition. Use of antivirals for suppression of HSV-2 for lowering the risk of HIV transmission cannot be overlooked until more light is shed on this topic. Therapeutic options that provide a complete eradication of HSV-2 including suppression of genital inflammation may be more relevant for decreasing HIV transmission in high HSV-2 prevalent regions.

\section{Conclusions}

The findings of this study which is first of its kind in North-east India, has provided a baseline data on HSV-2 seroprevalence and risk factors for future in-depth studies. The data provides a useful epidemiologic signal for a possible impending spike in HIV incidence among the young age group (22-25 years) as is indicated by a higher HSV-2 prevalence in this age group. Targeted public health awareness campaigns directed at high risk groups having multiple sexual partners, condom non-users, early coitarchal age, Christian community etc. are needed to be advocated for initiating successful intervention strategies to control HSV-2 and indirectly limiting HIV epidemic in Northeast India.

\section{Acknowledgements \\ We are thankful to Dr. B. C. Das, ICPO, Noida for providing us hands on training on various aspects of the study and Dr. Kanwar Narain of RMRC, Dibrugarh for his statistical support. We are also grateful to Dr. (Mrs.) Angshurekha Das, Dr. (Mrs.) Gargi Choudhuri, all the study participants and project staffs for their support in the study without which this study would have not been possible. This study was funded by Indian Council of Medical Research.}

\section{Author details}

'Regional Medical Research Centre, North East Region (Indian Council of Medical Research), Post Box-105, Dibrugarh-786001, Assam, India. ${ }^{2}$ Indian Council of Medical Research, Department of Health Research, (Ministry of Health \& Family Welfare), Ansari Nagar, New Delhi-110029, India. ${ }^{3}$ Assam Medical College \& Hospital, Dibrugarh-786001, Assam, India. ${ }^{4}$ Regional Institute of Medical Sciences, Lamphel-795004, Manipur, India. ${ }^{5}$ Directorate of Health Services, Naharlagun, Govt. of Arunachal Pradesh, India. ${ }^{6}$ Ganesh Das Hospital, Shillong-793001, Meghalaya, India. ${ }^{7}$ Aizawl Civil Hospital, Aizawl, Mizoram, India.

\section{Authors' contributions}

This study was conceived by KW with major contributions to design, drafting and critical revision of the manuscript by DB and JM. DB also performed the statistical analysis. BB performed the laboratory analysis, helped in data analysis and drafting the manuscript. LS, BA, LJ, AK and EZ contributed in collecting data, specimens, state level supervision and helped in drafting the manuscript. All authors approved the final version of the manuscript.

\section{Competing interests}

The authors declare that they have no competing interests.

Received: 7 December 2010 Accepted: 23 November 2011 Published: 23 November 2011

\section{References}

1. WHO and UNAIDS: Herpes simplex virus type 2: programmatic and research priorities in developing countries. Report of a WHO/UNAIDS/ LSHTM WORKSHOP, London 2001, 14-16 February, WHO/HIV_AIDS/ 2001.05.2001.

2. Smith JS, Robinson NJ: Age-specific prevalence of infection with herpes simplex virus types 2 and 1: A global review. J Infect Dis 2002, 186(Suppl1):S3-28.

3. Jennings JM, Louis TA, Ellen JM, Srikrishnan AK, Sivaram S, Mayer K, Solomon S, Kelly R, Celentano DD: Geographic Prevalence and Multilevel Determination of Community-level Factors Associated with Herpes Simplex Virus Type 2 Infection in Chennai, India. Am J Epidemiol 2008, 167(12):1495-1503.

4. Looker KJ, Garnetta GP, Schmid GP: An estimate of the global prevalence and incidence of herpes simplex virus type 2 infection. WHO Bulletin 2008, 86(10):805-13.

5. Sgaier SK, Mony P, Jaykumar S, McLaughlin C, Arora P, Kumar R, Bhatia P, Jha P: Prevalence and correlates of Herpes Simplex Virus-2 and syphilis infections in the general population in India. Sex Transm Infect 2011, 87:94-100.

6. Corey L: Synergistic Co pathogens - HIV-1 and HSV-2. N Engl J Med 2007, 356(8):854-856.

7. Mbizvo EM, Msuya Sia E, Stray-Pedersen B, Chirenje MZ, Munjoma M, Hussain A: Association of herpes simplex virus type 2 with human immunodeficiency virus among urban women in Zimbabwe. Int J STD AIDS 2002, 13:343-8.

8. Wald A, Link K: Risk of human immunodeficiency virus infection in herpes simplex virus type 2-seropositive persons: a meta-analysis. J Infect Dis 2002, 185(1):45-52.

9. Serwadda D, Gray RH, Sewankambo NK, Wabwire-Mangen F, Chen MZ, Quinn TC, Lutalo T, Kiwanuka N, Kigozi G, Nalugoda F, Meehan MP, Morrow RA, Wawer MJ: Human immunodeficiency virus acquisition associated with genital ulcer disease and herpes simplex virus type 2 infection: a nested case-control study in Rakai, Uganda. J Infect Dis 2003, 188(10):1492-7.

10. Holmberg SD, Stewart JA, Gerber AR, Byers RH, Lee FK, O'Malley PM, Nahmias AJ: Prior Herpes Simplex Virus Type 2 Infection as a Risk Factor for HIV Infection. JAMA 1988, 259:1048-1050.

11. Holmberg SD, Gerber AR, Stewart JA, Lee FK, O'Malley PM, Nahmias AJ: Herpes viruses as co-factors in AIDS. Lancet 1988, 2:746-747.

12. Reynolds SJ, Risbud AR, Shepherd ME, Zenilman JM, Brookmeyer RS, Paranjape RS, Divekar AD, Gangakhedkar RR, Ghate MV, Bollinger RC, Mehendale SM: Recent herpes simplex virus type 2 infection and the risk of human immunodeficiency virus type 1acquisition in India. $J$ Infect Dis 2003, 187:1513-21.

13. Corey $L$ : The current trend in genital herpes. Progress in prevention. Sex Transm Dis 1994, 21(suppl 2):S38-44.

14. Corey $L$, Wald A, Celum CL, Quinn TC: The effects of herpes simplex virus2 on HIV-1 acquisition and transmission: a review of two overlapping epidemics. J Acquir Immune Defic Syndr 2004, 35:435-445.

15. Zhu J, Hladik F, Woodward A, Klock A, Peng T, Johnston C, Remington M, Magaret A, Koelle DM, Wald A, Corey L: Persistence of HIV-1 receptorpositive cells after HSV-2 reactivation is a potential mechanism for increased HIV-1 acquisition. Nat Med 2009, 15:886-892.

16. Yahya-Malima IKhadija, Bjørg Evjen-Olsen, Matee IMecky, Knut Fylkesnes, Lars Haarr: HIV-1, HSV-2 and syphilis among pregnant women in a rural area of Tanzania: Prevalence and risk factors. BMC Infect Dis 2008, 8:75.

17. Nagot N, Ouédraogo A, Foulongne $V$, Konaté I, Weiss HA, Vergne L, Defer MC, Djagbaré D, Sanon A, Andonaba JB, Becquart P, Segondy M, Vallo R, Sawadogo A, Perre PVD, Mayaud P: Reduction of HIV-1 RNA levels with therapy to suppress herpes simplex virus. N Engl J Med 2007, 356:790-799.

18. Freeman EE, Weiss HA, Glynn JR, Cross PL, Whitworth JA, Hayes RJ: Herpes simplex virus 2 infection increases HIV acquisition in men and women: systematic review and meta-analysis of longitudinal studies. AIDS 2006, 20(1):73-83.

19. Abu-Raddad LJ, Magaret AS, Celum C, Wald A, Longini IM Jr, Self SG, Cory L: Genital herpes has played a more important role than any other sexually transmitted infection in driving HIV prevalence in Africa. PLOS ONE 2008, 3(5):e2230. 
20. Buvé A, Caraël M, Hayes RJ, Auvert B, Ferry B, Robinson NJ, Anagonou S, Kanhonou L, Laourou M, Abega S, Akam E, Zekeng L, Chege J, Kahindo M, Rutenberg N, Kaona F, Musonda R, Sukwa T, Morison L, Weiss HA, Laga M: The multicentre study on factors determining the differential spread of HIV in four African cities: summary and conclusions. AIDS 2001, 15(Suppl 4):S127-S131.

21. National AIDS Control Organization. [http://www.nacoonline.org/upload/ NACO\%2OPDF/Note\%20on\%20HIV\%20Sentinel\%20Surveillance\%20and\% 20HIV\%20Estimation_01\%20Feb\%2008.pdf], Accessed 28 April 2011.

22. Mahanta J, Medhi GK, Paranjape RS, Roy N, Kohli A, Akoijam SB, Dzuvichu B, Das HK, Goswami P, Thongamba G: Injecting and sexual behaviors, sexually transmitted infections and HIV prevalence in injecting drug users in three states in India. AIDS 2008, 22(Suppl 5):S59-S68.

23. Ural HSerdar: Genital Herpes in Pregnancy.[http://emedicine.medscape. com/article/274874-overview], Accessed 18 November 2011..

24. Ashly RL: Performance and use of HSV type-specific serology test kits. Herpes 2002, 9(2):38-45.

25. Chawla R, Bhalla P, Bhalla K, Singh MM, Garg S: Community-based study on seroprevalence of herpes simplex virus type 2 infection in New Delhi. Indian J Med Microbiol 2008, 26(1):34-9.

26. Wang H, Wang N, Chen RY, Sharp GB, Ma Y, Wang G, Ding G, Wu Z: Prevalence and predictors of herpes simplex virus type 2 infections among female sex workers in Yunnan Province, China. Int J STD AIDS 2008, 19(9):635-639.

27. Watson-Jones D, Weiss HA, Rusizoka M, Baisley K, Mugeye K, Changalucha J, Everett D, Balira R, Knight L, Ross D, Hayes RJ: Risk Factors for Herpes Simplex Virus Type 2 and HIV Among Women at High Risk in Northwestern Tanzania: Preparing for an HSV-2 Intervention Trial. J Acquir Immune Defic Syndr 2007, 46(5):631-642.

28. Glynn JR, Crampin AC, Ngwira BMM, Ndhlovu R, Mwanyongo O, Fine PEM: Herpes simplex virus type 2 trends in relation to the HIV epidemic in northern Malawi. Sex Transm Infect 2008, 84:356-360.

29. Anvikar AR, Rao VG, Savargaonkar DD, Rajiv Y, Bhondeley MK, Tiwari B, Karkare A, Luke C, Gadge V, Ukey M, Patel P: Seroprevalence of sexually transmitted viruses in the tribal population of Central India. Int J Infect Dis 2009, 13:37-39.

30. Mitra N, Gupta N: Seroprevalence and correlates of herpes simplex virus type-2 infection in a general gynaecology clinic. Arch Gynecol Obstet 2007, 275:19-23.

31. Rathore S, Jamwal A, Gupta V: Herpes simplex virus type 2: Seroprevalence in antenatal women. Indian J Sex Transm Dis 2010, 31:11-5.

32. Schneider JA, Lakshmi V, Dandona R, Kumar GA, Sudha T, Dandona L: Population-based seroprevalence of HSV-2 and syphilis in Andhra Pradesh state of India. BMC Infect Dis 2010, 10:59.

33. Xu F, Sternberg MR, Gottlieb SL, Berman SM, Markowitz LE, Forhan SE, Taylor LD: Seroprevalence of Herpes Simplex Virus Type 2 among Persons Aged 14-49 Years - United States, 2005-2008. MMWR 2010, 59(15):456-459.

34. Page A, Taylor R, Richters J, Shaw J, Taylor J, Cunningham A, Mindel A: Upstairs and downstairs: socio-economic and gender interactions in herpes simplex virus type 2 seroprevalence in Australia. Sex Transm Dis 2009, 36(6):344-9.

35. Buchacz K, McFarland W, Hernandez M, Klausner JD, Page-Shafer K, Padian N, Molitor F, Ruiz JD, Bolan G, Morrow S, Katz MH: Prevalence and correlates of herpes simplex virus type 2 infection in a population-based survey of young women in low-income neighborhoods of Northern California. Sex Transm Dis 2000, 27:393-400.

36. Siegel D, Golden E, Washington AE, Morse SA, Fullilove MT, Catania JA, Marin B, Hulley SB: Prevalence and correlates of herpes simplex infection: The population-based AIDS in Multiethnic Neighborhoods Study. JAMA 1992, 268:1702-8.

37. Weiss HA, Buvé A, Robinson NJ, Van Dyck E, Kahindo M, Anagonou S, Musonda R, Zekeng L, Morison L, Caraël M, Laga M, Hayes RJ: The epidemiology of HSV-2 infection and its association with HIV infection in four urban African populations. AIDS 2001, 15(Suppl 4):S97-S108.

38. Obasi A, Mosha F, Quigley M, Sekirassa Z, Gibbs T, Munguti K, Todd J, Grosskurth H, Mayaud P, Changalucha J, Brown D, Mabey D, Hayes R: Antibody to herpes simplex virus type 2 as a marker of sexual risk behavior in rural Tanzania. J Infect Dis 1999, 179(1):16-24.
39. Nilsen A, Mwakagile D, Marsden H, Langeland N, Matre R, Haarr L: Genital Herpes Simplex Virus Infection. Forum for Nord Derm Ven 2008, 46, Dissertations Vol. 13 (2).

40. Tideman RL, Taylor J, Marks C, Seifert C, Berry G, Trudinger B, Cunningham A, Mindel A: Sexual and demographic risk factors for herpes simplex type 1 and 2 in women attending an antenatal clinic. Sex Transm Infect 2001, 77:413-415.

41. Tobian AAR, Serwadda D, Quinn TC, Kigozi G, Gravitt PE, Laeyendecker O, Charvat B, Ssempijja V, Riedesel M, Oliver AE, Nowak RG, Moulton LH, Chen MZ, Reynolds SJ, Wawer MJ, Gray RH: Male circumcision for the prevention of HSV-2 and HPV infections and syphilis. N Engl J Med 2009, 360:1298-1309

42. Wald A, Zeh J, Selke S, Warren T, Ryncarz AJ, Ashley R, Krieger JN, Corey L: Reactivation of Genital Herpes Simplex Virus Type 2 Infection in Asymptomatic Seropositive Persons. N Engl J Med 2000, 342:844-850.

43. Ray K, Bala M, Bhattacharya M, Muralidhar S, Kumari M, Salhan S: Prevalence of RTI/STI agents and HIV infection in symptomatic and asymptomatic women attending peripheral health set-ups in Delhi, India. Epidemiol Infect 2008, 136(10):1432-1440.

44. Celum C, Wald A, Lingappa JR, Magaret AS, Wang RS, Mugo N, Mujugira A, Baeten JM, Mullins Jl, Hughes JP, Bukusi EA, Cohen CR, Katabira E, Ronald A, Kiarie J, Farquhar C, Stewart GJ, Makhema J, Essex M, Were E, Fife KH, Bruyn GD, Gray GE, McIntyre JA, Manongi R, Kapiga S, Coetzee D, Allen S, Inambao M, Kayitenkore K, et al: Acyclovir and Transmission of HIV-1 from Persons Infected with HIV-1 and HSV-2. N Engl J Med 2010, 362:427-439.

45. Watson-Jones D, Weiss HA, Rusizoka M, Changalucha J, Baisley K, Mugeye K, Tanton C, Ross D, Everett D, Clayton T, Knight L, Hambleton I, Goff JL, Belec L, Hayes R: Effect of Herpes Simplex Suppression on Incidence of HIV among Women in Tanzania. N Engl J Med 2008, 358:1560-1571.

46. Lisco A, Vanpouille C, Tchesnokov EP, Grivel JC, Biancotto A, Brichacek B, Elliott J, Fromentin E, Shattock R, Anton P, Gorelick R, Balzarini J, McGuigan C, Derudas M, Gotte M, Schinazi RF, Margolis L: Acyclovir is activated into a HIV-1 reverse transcriptase inhibitor in herpes virusinfected human tissues. Cell Host Microbe 2008, 4:260-270.

47. McMahon MA, Siliciano JD, Lai J, Liu JO, Stivers JT, Siliciano RF, Kohli RM: The Antiherpetic Drug Acyclovir Inhibits HIV Replication and Selects the V75I Reverse Transcriptase Multidrug Resistance Mutation. J Biol Chem 2008, 283:31289-31293.

\section{Pre-publication history}

The pre-publication history for this paper can be accessed here: http://www.biomedcentral.com/1471-2334/11/325/prepub

doi:10.1186/1471-2334-11-325

Cite this article as: Biswas et al:: Seroprevalence and risk factors of herpes simplex virus type-2 infection among pregnant women in Northeast India. BMC Infectious Diseases 2011 11:325.

\section{Submit your next manuscript to BioMed Central and take full advantage of:}

- Convenient online submission

- Thorough peer review

- No space constraints or color figure charges

- Immediate publication on acceptance

- Inclusion in PubMed, CAS, Scopus and Google Scholar

- Research which is freely available for redistribution

Submit your manuscript at www.biomedcentral.com/submit
C) Biomed Central 